\title{
The intelligent lockdown: Compliance with COVID-19 mitigation measures in the Netherlands
}

\author{
Malouke Esra Kuiper*<, Anne Leonore de Bruijn*, Chris Reinders Folmer*, Elke Olthuis*, \\ Megan Brownlee*, Emmeke Barbara Kooistra*, Adam Fine^ ${ }^{\wedge}$ \& Benjamin van Rooij* ${ }_{ \pm<}$ \\ *University of Amsterdam, School of Law \\ \pm University of California, Irvine, School of Law \\ $\wedge$ Arizona State University, School of Criminology and Criminal Justice \\ <corresponding authors: m.e.kuiper@uva.nl,b.vanrooij@uva.nl
}

\begin{abstract}
In response to the COVID-19 pandemic, the Dutch government has introduced an "intelligent lockdown" with stay at home and social distancing measures. The Dutch approach to mitigate the virus focuses less on repression and more on moral appeals and self-discipline. This study assessed what factors influence whether Dutch people comply with the measures. We analyzed data from an online survey $(N=568)$ conducted between April 7-14. The overall results showed that reported compliance was high. Analyzing what shaped such compliance, shows that the the Dutch approach has to some extent worked as hoped in practice. Repression did not play a significant role in compliance, while intrinsic (moral and social) motivations promoted compliance. Yet appeals on self-discipline did not work for everyone, and people who reported more impulsivity were more likely to violate the rules. In addition, compliance was lower for people who lacked the practical capacity to follow the measures and for those who have the opportunity to break the measures. Sustained compliance, therefore, relies on support to aid people to maintain social distancing and restrictions to reduce opportunities for unsafe gatherings. These findings suggest several important practical recommendations for combating the COVID-19 pandemic.
\end{abstract}

\section{Introduction}

The new SARS-CoV-2 virus (also known as Coronavirus; the cause of Corona Virus Disease (COVID-19), which originated in Wuhan, China in December 2019) has rapidly spread across the world, and resulted in a once-in-a-century pandemic (Gates 2020, Zhou et al. 2020). As no treatment or vaccine is available yet, individual behavior is crucial to mitigate the spread of this virus (Anderson et al. 2020, Chen et al. 2020). Various measures to further contain the spread have been initiated globally, such as social distancing, quarantine, isolation, or community containment (Anderson et al. 2020, Wilder-Smith and Freedman 2020). But in order for such measures to be effective, it is crucial that citizens effectively comply with them (Sailer et al. 
2020). As such, compliance with the mitigation measures is essential to decrease mortality and to reduce an overburden of health care systems (Walker et al. 2020).

This paper studies compliance with COVID-19 mitigation measures in the Netherlands. The Dutch authorities have adopted a combination of stay at home and social distancing measures that they have labeled as an "intelligent lockdown." With this, the Dutch measures contrast with those in most other European countries that allow far less freedom of movement. Whereas people in Italy, Spain, or France are only allowed to leave their house under certain circumstances (e.g., grocery shopping or medical needs), people in the Netherlands were still allowed to go outside for a walk or a work-out by themselves. Parks and beaches were still open, and people did not need proof of the essentiality to be outside. ${ }^{\text {ii }}$ Instead, with the intelligent lockdown, the Dutch Government appealed to people's own responsibility and selfdiscipline. Dutch Prime Minister Mark Rutte underlined this in one of his speeches, by stating that the Netherlands is a "mature democratic country" which does not need a government that tells people what to do. ${ }^{\text {ii }}$

This study seeks to investigate the Dutch approach to mitigate the COVID-19 pandemic. Specifically, we aim to answer the following two questions. First, we investigate to what extent people report compliance with the measures. Second, we examine what factors have played a role in shaping people's compliance with the with the measures based on insights from prior compliance research.

In answering these questions, we hope to shed light into on the effectiveness of the Dutch approach that primarily focused on peoples' own responsibility and self-discipline.

\section{Literature overview}

Several authors have published reviews of insights from social and behavioral sciences to give governments and policy-makers recommendations on how to fight the outbreak of 
COVID-19 from a behavioral point of view. For example, Lunn et al. (2020) provided a narrative review on evidence from behavioral science, covering 5 issues: handwashing, face touching, self-isolation, public-spirited behavior, and responses to crisis communication. Based on their review, their main finding was that the effectiveness of communication stands out as a crucial issue to generate desirable behavior. Furthermore, Van Bavel et al. (2020) provided a review of insights from social and behavioral sciences on how to align human behavior with recommendations from health care experts and epidemiologists. They used evidence from a selection of research topics relevant to pandemics, such as social and cultural influences on behavior, moral decision-making, and leadership. Although we can learn some lessons from previous pandemics such as Influenza A, the COVID-19 pandemic differs from other pandemics (e.g., the reproduction number), and a lot is still unknown about the current pandemic (Anderson et al. 2020). This means that additional insight into how and why individuals respond to the specific COVID-19 measures is necessary. Thus, it is crucial to test a wide set of factors that may influence people's compliance with the measures to contain COVID-19 to get a broader understanding of what influences compliance with the measures.

Fortunately, there is a rapidly growing body of research into social responses to COVID19, including research regarding compliance with the mitigation measures. Studies have examined the variation in compliance globally (Fetzer et al. 2020), or specifically within the Netherlands (I\&O Research and Universiteit Twente 2020). Others have looked into more specific factors that are associated with compliance. For example, Zettler et al. (2020) investigated whether various personality characteristics could be linked to people's willingness in accepting personal restrictions for fighting COVID-19 with a Danish sample. Results of the study showed that Emotionality (from the HEXACO Personality Scale), as well as Dark Factor of Personality explained who were more willing to accept restrictions. A study conducted in Germany, the United States ("US"), and the United Kingdom ("UK") showed that empathy for 
vulnerable members of the society was associated with compliance (Pfattheicher et al. 2020). In the US, studies found that subjective self-interest was also associated with compliance (Oosterhoff and Palmer 2020). In the US, political orientation was associated with compliance (Kushner Gadarian, Goodman, and Pepinsky 2020, Painter and Qiu 2020), in contrast to the UK, where political orientation was not associated with compliance (Harper et al. 2020). Plohl and Musil (2020) found in their global sample that trust in science predicts compliance with COVID-19 measures; people who have greater trust in science appeared to show greater compliance. Sailer et al. (2020) found that in the US, more science knowledge and trust in medicine affects individual behavior, motivating, for example, social distancing. The perceived fear of the COVID-19 virus is globally associated with increased compliance (Harper et al. 2020). Results of this study showed that people with greater fear of COVID-19 are more likely to positively change their behaviors (i.e., social distancing, improved hand washing). A study in Italy found that being negatively surprised by a hypothetical extension of the measures was associated with a lower willingness to comply (Briscese et al. 2020). Wright et al. (2020), found that in the US, economic endowments meaningfully influence compliance with stay at home measures and that targeted economic aid may enhance the effectiveness of local stay at home policies. Thus, prior research has identified a range of individual and contextual factors that may impact compliance with mitigation measures.

Nevertheless, these studies have only focused on a small number of possible factors that potentially influence compliance with the measures. They have not focused specifically on variables that are known to affect compliance (van Rooij and Sokol 2021 (Forthcoming)).

\section{The COVID-19 response in the Netherlands}

We conducted an online survey in the Netherlands between April 7 and April 14 to study the influence of various factors on people's compliance with two key mitigation measures: stay 
at home orders and social distancing. These measures were applied in the whole of the Netherlands at the time. ${ }^{\text {iv }}$ The first patient was tested positively for COVID-19 in the Netherlands on February 27, 2020. ${ }^{\mathrm{v}}$ This led to a first set of measures that were adopted on March 6, namely that residents of the province of North-Brabant, where most confirmed Coronavirus cases appeared, were ordered to work from home as much as possible, and all citizens that showed any COVID-19 related symptoms should stay at home. ${ }^{\mathrm{vi}}$ On March 9, authorities advised to stop shaking hands, in an addition to the hygiene measures of washing hands for a minimum of 20 seconds and sneezing into their elbow. ${ }^{\text {vii }}$ On March 12, authorities proclaimed a stay at home measure, and everyone was asked to work from home if possible or to spread workhours. Also, all events and gatherings with more than 100 people were prohibited. ${ }^{\text {viii }}$ In addition, colleges and universities were ordered to switch to online teaching platforms. Quickly after, on March 15, the authorities ordered the closure of all schools, cafes and restaurants, and sport locations. Citizens were also asked to try to stay inside as much as possible, with exception for essential activities such as grocery shopping, helping others, or for fresh air. Furthermore, citizens were asked to always keep a safe distance of 1.5 meters from others outside of their own household. ${ }^{\text {ix }}$ In response to crowded beaches and parks during the weekend of March 21-22, the Government sharpened the measures. Events were canceled until June 1, gatherings of three people or more outside of one's direct household were banned, businesses in contact-based industries were shut down, and places such as shops or public transit that could not guarantee the 1.5-meter distance had to close. ${ }^{\mathrm{x}}$ The measures were extended until May 20, and they will be evaluated the week prior to the now standing end date. ${ }^{\mathrm{xi}}$

The Dutch approach to mitigate COVID-19 seeks to reduce social contacts while still allowing some individual freedom. To implement this so-called "intelligent lockdown," authorities have stressed that people's own sense of responsibility and their self-discipline are vital. Authorities have appealed to people's sense of morality. They have asked Dutch people 
to help "flatten the curve" so that intensive care units can cope with the flood of serious Coronavirus cases. ${ }^{\text {xii }}$ They have also morally condemned citizens that decided to visit crowded beaches and parks in the weekend of March 21-22. For instance, Prime Minister Rutte described such people anti-social and uncivilized. ${ }^{\text {xii }}$ In the same speech he asked people for solidarity, especially he addressed his words to younger people that may think they are less at risk. Explicitly, he said: "maybe not for yourself, but you do not live for yourself only, we are with 17 million people in this country, do this for the elderly, people with poor health, who do run a risk when you infect them." ${ }^{\text {xiv }}$ A couple of weeks into the measures, the Prime Minister asked people continue to follow the guidelines and stay at home as much as possible. He explained: "[i]f people think they can ease up with the measures, we immediately see a new spike in cases". ${ }^{\mathrm{xv}}$

Beside the appeal to own responsibility and self-discipline, the Dutch Government used several other approaches to ensure compliance with the measures. After many people ignored the measures during the weekend of March 21-22, ${ }^{\text {xvi }}$ fines were introduced. People who violated the rules could receive a warning or a fine up to $€ 400$, ${ }^{\text {vii }}$ and by April 23, authorities had issued over 5,500 fines. ${ }^{\text {xiii }}$ Municipalities got the authority to close down public venues if necessary, ${ }^{\text {xix }}$ for example, Amsterdam closed its canals to prohibit people from boating, ${ }^{\mathrm{xx}}$ and Lisse closed its roads to the flower fields after a busy Easter Saturday. ${ }^{x x i}$ To prevent great negative consequences from the crisis, the Government introduced several measures such as the economic measure of compensation for labor costs for companies, ${ }^{\text {xxii }}$ or the ban on evictions. ${ }^{\text {xxiii }}$ Moreover, authorities have raised awareness of the measures by using campaigns on television, radio, posters in public venues, and social media, called "[o]nly together we can control Corona: wash your hands, stay at home, and keep distance". ${ }^{x i v}$ As a final approach, authorities have emphasized that most citizens are in compliance. Prime Minister Rutte explained in his speech on March 23: “[m]ost of us comply with the measures, almost all do so (...) when you see the 
empty streets, the empty offices, the empty highways, the empty train platforms, I think the message has landed with many people in the country, and many comply with the measures." ${ }^{\mathrm{xxv}}$ Prime Minister Rutte additionally attempted to emphasize the norm of 1.5 meters of distance, as he referred to the society as a "one-and-a-half-meter-society."xxvi

\section{The present study}

The present study aimed to examine citizens' compliance with these measures, as well as the factors that contributed to this. To this end, respondents were asked to report the frequency in which they had engaged in behaviors desired or prohibited by the measures. The first subset of questions focused on social distancing: the extent to which people kept the recommended 1.5-meter distance from others outside their direct household and refrained from meeting people outside of their direct household. The other subset of questions focused on staying at home as much as possible, and only going outside for essential activities.

Additionally, this study assessed a set of factors that potentially shaped the way people have responded to the measures, based on insights from literature of psychology, criminology, sociology, and economy on why people obey or break rules (Feldman 2018, Friedman 2016, van Rooij and Sokol 2021 (Forthcoming)).

The first factor we expected to influence compliance with the mitigation measures is the extent to which people agreed with the substance of the measures, also known as substantive moral support (Tyler 1997, 2006). First, we asked participants how they perceived the threat of the virus for themselves, loved ones, and public health in general. Second, we assessed whether they morally supported the measures themselves. Third, we studied to what extent people thought the overall approach taken by the authorities was consistent and adequate. We used these elements to study whether more moral support for the measures was associated with higher compliance. 
Second, we studied whether costs of compliance and strain experience from following the measures were associated with compliance. Based on the theory of rational choice (Donovan and Blake 1992, Paternoster and Simpson 1993), we expected that higher costs of compliance would be associated with less compliance. In addition, we expected that people who experienced more strain and negative emotions because of the measures would display lower compliance, based on strain theory. This assumes that people might cope with the negative emotions and strain by violating the rules (Agnew 1992, 2007, Agnew et al. 2002, Agnew and White 1992, Baron 2004, Botchkovar, Tittle, and Antonaccio 2009, Piquero and Sealock 2004).

As a third factor that may influence compliance, we studied the deterrent effect of the measures. According to general deterrence theory, people comply more with rules when there is a greater certainty and severity of punishment (Becker 1968, Polinsky and Shavell 2000, Shavell 1991). There is no conclusive evidence that stronger punishment alone deters (Braga, Weisburd, and Turchan 2019); this only has an effect after there is a threshold level of certainty of punishment (Brown 1978, Chamlin 1991, Nagin 2013). In addition, the perception of punishment is important (Waldo and Chiricos 1972). Research shows that deterrence is a subjective mechanism (Apel 2013, Decker, Wright, and Logie 1993), and, therefore, it is important to study both the perceptions people have of certainty of punishment as well as the impact it may have on their lives (Grasmick and Bryjak 1980). We expected that greater certainty and greater severity of punishment would have a deterrent effect, and therefore would result in more compliant behavior with the measures.

The fourth factor we expected to influence compliance was the capacity people have to comply with mitigation measures. It makes sense that, if people are practically unable to comply with the rules, they would be less likely to report compliant behavior. For people to have the capacity to comply, it is also important that they have sufficient knowledge of what is expected 
of them (Darley, Carlsmith, and Robinson 2001, Kim 1999, van Rooij 2021 (Forthcoming)). Therefore, we expected that people with more knowledge of the rules, would report more compliant behavior. Finally, we expected that the more unclear the rules were to people, the more difficult it was to know what was expected from them, which would therefore lead to less compliant behavior (Feldman and Teichman 2009).

Fifth, we expected that people with less opportunity to break the rules would report less rule breaking, based on insights from routine activities theory (Cohen and Felson 1979, Osgood et al. 1996, Spano and Freilich 2009) and situational crime prevention (Clarke 2003, 2005).

A sixth factor we expected may influence compliance was an individual's level of impulsivity. Previous criminological findings have shown that high levels of impulsivity predict deviant behavior (Gottfredson and Hirschi 1990, Pratt and Cullen 2000, 2005, Pratt and Llouyd 2021 (Forthcoming), Vazsonyi, Mikuška, and Kelley 2017), therefore, we expected that higher levels of impulsivity to be associated with lower levels of compliance.

As a seventh possible factor, we expected descriptive social norm to influence compliance. Research has shown that people are more likely to comply when they see others comply with rules of requests. Research has also found that the more people see others violate rules, the more likely they are to violate the rules themselves (Cialdini et al. 2006, Cialdini and Trost 1998, Goldstein, Cialdini, and Griskevicius 2008, Schultz et al. 2007). We studied whether perceptions of whether others followed the rules predicted respondent's own compliance.

The eighth factor we expected to be associated with compliance was obligation to obey the law ("OOL") and procedural justice ("PJ"). People who feel more obligated to obey the law are more likely to comply (Tyler 2006). OOL appears to have two dimensions. First, OOL has a normative dimension; people voluntarily obey the rules if these are made in a procedurally just way, by a properly established authority (Fine et al. 2020, Fine et al. 2016, Nagin and Telep 
2017, Tyler 1997, 2006, 2017). When people think that the rules are created and enforced by authorities in a procedurally fair and just manner, there is a greater OOL (Nagin and Telep 2017, Tyler 1997, 2006, 2017, Walters and Bolger 2019). Second, OOL has a non-normative dimension; when people feel that they have no other choice but to obey, they rather obey out of coercion and fear of authorities (Posch et al. 2020). We expected that normative OOL ("NOOL"), non-normative OOL ("NN-OOL"), and PJ would be associated with greater compliance.

The ninth factor that we expected to influence compliance is political orientation. People learned about the pandemic and its measures through news and social media, communication sources that could be aligned with a particular political orientation (Baum and Groeling 2008, Fletcher and Nielsen 2017, Prior 2013, Spohr 2017). This could determine the way that people learned about the pandemic and may have influenced how they viewed the measures and authorities (Fine, Rowan, and Simmons 2019) which, eventually, affected whether they complied or not. This is in line with previous work on political orientation and compliance with COVID-19 measures (Kushner Gadarian, Goodman, and Pepinsky 2020, Painter and Qiu 2020). Thus, we studied the association between political orientation and compliance.

\section{Methods}

Ethical approval was obtained from the Ethics Review Board of the University of Amsterdam on April 3, 2020. All participants provided consent before participating in the study. Participation was voluntary, and all participants could stop the survey at any time.

\section{Participants}

Participants were recruited through the online platform Prolific Academic and were redirected to Qualtrics to fill out an English survey. Only English-speaking residents of the 
Netherlands ${ }^{1}$ over the age of 18 were allowed to participate in the survey and were paid $\$ 3.00$ for participation. The sample consisted of $N=614$ participants of which 32 participants were excluded for not finishing the survey. Furthermore, eight participants were excluded because they provided professional care for COVID-19 patients, and seven participants were excluded because they failed the attention check. ${ }^{2}$ Table 1 shows the sample characteristics.

Table 1.

Sample characteristics for $\mathrm{N}=568$.

\begin{tabular}{ll}
\hline Characteristic & \\
\hline Age (Mean (SD)) & $27.55(8.50)$ \\
Gender & \\
Female & $44.2 \%$ \\
Male & $54.8 \%$ \\
Other (non-binary) & $1.1 \%$ \\
Yes & \\
No & $16.9 \%$ \\
Ethnic minority & $81.0 \%$ \\
No diploma & \\
High school degree & $1.2 \%$ \\
College degree and higher & $35.8 \%$ \\
Vducation & $63.0 \%$ \\
Sery progressive & \\
Slightly progressive & $29.6 \%$ \\
Slightly conservative & $42.3 \%$ \\
Very conservative & $13.6 \%$ \\
\hline
\end{tabular}

Note. Ethnic minority and political view - percentages may not add up to $100 \%$ as subjects could select the option "prefer Materials not to say"

Control variables. The following descriptive statistics were recorded: age, gender, nationality, information on residency (country, province), employment status, occupation, education, household residents (total number and number of children or minors), part of ethnic minority, social economic status before and after COVID-19 (MacArthur Scale of Subjective Social Status; Adler et al. 2000). Furthermore, participants indicated whether they provided professional care for COVID-19 patients, whether they visited friends or family over the age of 75 on a regular basis prior to the outbreak of the virus, and whether they themselves or anyone

\footnotetext{
${ }^{1}$ The Netherlands is ranked first regarding English skills after exclusion of native English countries (https://www.ef.com/wwen/epi/); more than $90 \%$ of Dutch people rate themselves as reasonable to fluent in English (Edwards 2014).

${ }^{2}$ One participant was excluded based on overlap in exclusion criteria; both providing professional care and failing the attention check
} 
they knew had underlying health issues that would make them more at-risk for contracting COVID-19. Finally, participants were asked to indicate their trust in science (on a single item taken from McCright et al. 2013), and trust in media reporting on a single item, similar to the item of trust in science.

Compliance with COVID-19 measures. Compliance was measured on two main COVID-19 mitigation measures: "social distancing" and "stay at home" measures. Four items $(\alpha=.65)$ measured whether participants complied with social distancing measures. For social distancing, three items were reverse scored. Compliance with stay at home measures was measured using a single item. Participants answered on a 7-point Likert scale ranging from (1) "never" to (7) "always." A factor analysis of the compliance measures resulted in all items loading on one factor. We therefore decided to use the combined compliance measure for further analysis, despite that the combined compliance measures $(\alpha=.68)$ did not reach the often-used cut-off point of $\alpha=.70$. Higher values indicated greater compliance with COVID19 mitigation measures.

Substantive moral support. Substantive moral support was measured on three subscales; perceived threat, specific moral alignment, and support for current policies.

Perceived threat. Perceived threat was measured using three items $(\alpha=.76)$, on which participants indicated to what extent they believed the Coronavirus was a threat to themselves, friends and relatives, or the general public, rated on a 7-point Likert scale ranging from (1) “very strongly disagree" to (7) “very strongly agree." Higher scores indicated higher perceived threat.

Specific moral alignment. Specific moral alignment was measured using two items $(\alpha$ $=.85)$, on which participants indicated to what extent they believed people should follow the COVID-19 mitigation measures, rated on a 7-point Likert scale ranging from (1) "very strongly 
disagree" to (7) "very strongly agree." The mean score was calculated and higher values indicated more specific moral alignment.

Support for current policies. Support for current policies was measured using three items $(\alpha=.40)$, on which participants indicated to what extent they supported the authorities in adopting the COVID-19 mitigation measures, rated on a 7-point Likert scale ranging from (1) "very strongly disagree" to (7) "very strongly agree." One item was reverse scored. The mean score was calculated and higher values indicated more support for the authorities adopting the COVID-19 measures. One item correlated poorly. If removed, Cronbach's alpha rose to $\alpha=$ .77 , and this item was excluded from further analysis.

Costs of compliance and strain. Costs of compliance and strain were measured on two sub-scales; costs of compliance, and negative emotions.

Costs of compliance. Participants indicated on five items $(\alpha=.74)$ how likely it was that compliance with the COVID-19 mitigation measures would have a negative impact on them. Participants answered on a 7-point Likert scale ranging from (1) "extremely unlikely" to (7) "extremely likely." A higher score indicated that people thought it was more likely that COVID-19 measures would have a negative impact on them.

Negative emotions. Negative emotions due to COVID-19 was measured on six items ( $\alpha=.84$ ) assessing different negative emotions, rated on a 7-point Likert scale ranging from (1) "very strongly disagree" tot (7) "very strongly agree." Means were calculated and higher values indicated higher negative emotions.

Deterrence. Deterrence was measured for the two COVID-19 mitigation measures separately on two subscales: certainty and severity.

Certainty. Two items (social distancing $\alpha=.72$; stay at home $\alpha=.81$ ) measured the perceived certainty of apprehension and punishment for violating COVID-19 measures, answered on a 7-point Likert scale ranging from (1) "extremely improbable" to (7) "extremely 
probable." As the two items for social distancing and stay at home measures showed strong internal consistency $(\alpha=.80)$, they were combined into aggregated scale measures of certainty of punishment. Higher scores indicated greater certainty of punishment for violating COVID19 measures.

Severity. On one item for the severity of punishment, participants indicated how much they believed they would suffer if punished for violating COVID-19 measures. Subjective severity of punishment (social distancing and stay at home combined $\alpha=.88$ ) was answered on a 6-point Likert scale ranging from (1) "extreme suffering" to (6) "no suffering at all." Higher scored indicated lower suffering from punishment for violating COVID-19 measures.

Capacity to comply. The capacity to comply was measured using three subscales; practical capacity to comply, knowledge of the current measures, and perceived clarity of current measures.

Practical capacity to comply. Three items $(\alpha=.53)$ measured to what extent participants are practically able to comply with the COVID-19 mitigation measures, on a 7-point Likert scale ranging from (1) "very strongly disagree" to (7) "very strongly agree." One item correlated poorly ( $\alpha=.54$ if deleted). This item was excluded from further analysis. Higher scores indicated more practical ability to comply.

Knowledge of current measures. Participants indicated for seven statements which COVID-19 mitigation measures currently apply to them, with three answer options (yes/no/unsure). As all measures were in force within the Netherlands at time this survey was conducted, the total number of "yes" answers given (range 0-7) was used as an indicator of legal knowledge. Higher scores indicated more knowledge of current measures.

Perceived clarity of current measures. Furthermore, participants were asked on one item whether the COVID-19 measures were clear to them (" $[t]$ he measures authorities have adopted to reduce the spread of the Coronavirus are...") answered on a 7-point Likert scale 
ranging from (1) "extremely unclear" to "extremely clear," where higher scores indicated greater clarity of the current measures.

Opportunity to violate. Five items $(\alpha=.78)$ measured to what extent participants had the opportunity in practice to violate the COVID-19 mitigation measures, on a 7-point Likert scale ranging from (1) "very strongly disagree" to (7) "very strongly agree." Higher scores indicated more opportunity to violate the COVID-19 mitigation measures.

Impulsivity. Impulsivity was measured using a subset of five items $(\alpha=.76)$ taken from the 8-item impulse control subscale from the Weinberger Adjustment Inventory (WAI; Weinberger and Schwartz 1990). The items were answered on a 5-point Likert scale ranging from (1) "false" to (5) "true." One item was reverse scored, and means were calculated such that higher scores indicated higher impulsivity.

Descriptive social norms. Participants rated to what extent people they know comply with the COVID-19 measures (one item for each measure, $\alpha=.87$ ), on a 7-point Likert scale ranging from (1) “very strongly disagree” to (7) “very strongly agree.” Higher scores indicated more compliant descriptive social norms.

Obligation to obey the law (OOL). OOL was measured using three subscales; normative obligation to obey the law, non-normative obligation to obey the law, and procedural justice.

Normative obligation to obey the law. Normative obligation to obey the law was measured with a single item, "I feel like it is sometimes okay to break the law", on a 7-point Likert scale ranging from (1) "strongly agree" to (7) "strongly disagree." This item was created for the current study based on existent work (e.g., Estévez and Emler 2010, Fine et al. 2020, Reisig, Bratton, and Gertz 2007). Higher scores indicated greater normative obligation to obey the law. 
Non-normative obligation to obey the law. Non-normative obligation to obey the law was measured using a single item, "I only obey the authorities handling the Coronavirus because I am afraid of them" (adapted for this study following Posch et al. 2020, Tankebe, Reisig, and Wang 2016), measured on a 7-point Likert scale ranging from (1) "very strongly disagree" to (7) "very strongly agree." Higher scores indicated higher non-normative obligation to obey the law.

Procedural justice (PJ). PJ was measured by adapting instruments for evaluating perceived fairness of law enforcement (Baker and Gau 2018, Gau 2014, Tyler 1997, Wolfe et al. 2016). Three items measured PJ in creating the COVID-19 mitigation measures, and four items measured PJ in enforcing the COVID-19 mitigation measures. The items were answered on a 7-point Likert scare ranging from (1) "very strongly disagree" to (7) "very strongly agree." Because the PJ perceptions for creation and enforcement were strongly correlated $(\alpha=.91)$, we used a scale with the combined PJ, with higher values indicating higher PJ.

Political orientation. Political orientation was measured with a single item (adapted from Fine, Rowan, and Simmons 2019, Hasson et al. 2018, Wojcik et al. 2015) with four answer possibilities, ranging from "very progressive" to "very conservative." Additionally, participants could indicate that they "prefer not to say." If so, they were excluded from analyses that include this variable.

\section{Results}

\section{Compliance with COVID-19 measures}

Table 2 shows the descriptive statistics of the compliance with COVID-19 measures. For all items means were considerably large, indicating that overall, participants self-reported high rates of compliance. 
Table 2.

Descriptive statistics of Compliance with COVID-19 measures on a 7-point Likert scale from (1) "never” to (7) “always".

\begin{tabular}{|c|c|c|}
\hline Item & Mean & $\mathrm{Sd}$ \\
\hline \multicolumn{3}{|l|}{ Since the authorities took measures to contain the Coronavirus: } \\
\hline \multicolumn{3}{|l|}{ Social distancing } \\
\hline I still meet people outside of my direct household.^${ }^{\wedge}$ & 5.89 & 1.11 \\
\hline I keep a safe distance from people outside of my direct household. & 6.04 & 1.15 \\
\hline I still visit others (friends, relatives) outside of my direct household.^ & 6.24 & 0.96 \\
\hline I still allow others (friends, relative) to visit my direct household. ${ }^{\wedge}$ & 6.15 & 0.98 \\
\hline \multicolumn{3}{|l|}{ Stay at home } \\
\hline $\begin{array}{l}\text { I have stayed at home after I was ordered to do so, apart from engaging } \\
\text { in essential activities (e.g., grocery shopping, medical appointments) }\end{array}$ & 5.93 & 1.24 \\
\hline Combined measure & 6.05 & 0.73 \\
\hline
\end{tabular}

Note. $^{\wedge}$ - reverse scored.

\section{Descriptive statistics}

Table 3 shows the descriptive statistics for the control variables. Table 4 shows the descriptive statistics for independent variables.

Table 3.

Descriptive statistics $(\mathrm{M}(\mathrm{SD})$, or percentages) of control variables for $\mathrm{N}=568$.

\begin{tabular}{llc}
\hline Variables & $\begin{array}{l}\text { Descriptive } \\
\text { Statistics }\end{array}$ & Scale \\
\hline N household & & \\
N children & & \\
SES pre-COVID-19 & $6.34(1.56)$ & $1-10$ \\
SES post-COVID-19 & $6.26(1.67)$ & $1-10$ \\
Friends/family 75+ & $34.5 \%$ & \\
Health issues self & $13.0 \%$ & \\
Health issues others & $74.6 \%$ & \\
Trust in science & $4.29(0.80)$ & $1-5$ \\
Trust in media & $2.93(1.11)$ & $1-5$ \\
\hline
\end{tabular}


Table 4.

Descriptive statistics $(\mathrm{M}(\mathrm{SD})$ of independent variables for $\mathrm{N}=568$.

\begin{tabular}{lll}
\hline Variables & $\mathrm{M}(\mathrm{SD})$ & Scale \\
\hline Substantive moral alignment & & \\
$\quad$ Perceived threat & $4.97(1.10)$ & $1-7$ \\
$\quad$ Specific moral alignment & $6.25(1.06)$ & $1-7$ \\
$\quad$ Support current policies & $4.47(1.19)$ & $1-7$ \\
Costs of compliance & $4.03(1.34)$ & $1-7$ \\
Negative emotions & $4.09(1.16)$ & $1-7$ \\
Deterrence & & \\
$\quad$ Certainty & $3.48(1.27)$ & $1-7$ \\
$\quad$ Severity & $3.62(1.15)$ & $1-6$ \\
Capacity to comply & & \\
$\quad$ Practical capacity to comply & $5.50(1.12)$ & $1-7$ \\
$\quad$ Knowledge & $5.22(1.67)$ & $0-7$ \\
$\quad$ Clarity of current measures & $5.32(1.32)$ & $1-7$ \\
Opportunity to comply & $3.85(1.38)$ & $1-7$ \\
Impulsivity & $2.11(0.80)$ & $1-5$ \\
Descriptive social norms & $5.40(1.15)$ & $1-7$ \\
OOL and PJ & & \\
$\quad$ Normative OOL & $4.36(1.70)$ & $1-7$ \\
$\quad$ Non-normative OOL & $2.12(1.20)$ & $1-7$ \\
PJ & $5.35(1.10)$ & $1-7$ \\
\hline
\end{tabular}

\section{Correlations}

Table 5 shows the correlations between the compliance measure and the control variables. Table 6 shows the correlations between the compliance measure and the independent variables. We found a positive correlation between compliance and (i) perceived threat $(r=$ .23 ), (ii) specific moral alignment $(r=.37)$, (iii) negative emotions $(r=.07)$, (iv) capacity to comply $(r=.29)$, (v) clarity of current measures $(r=.08)$, (vi) knowledge of current measures $(r=.24)$, (vii) social norms $(r=.07)$, (viii) normative OOL $(r=.19)$, and (ix) PJ $(r=.08)$. This suggests that more perceived threat, greater specific moral alignment, more negative emotions, more capacity to comply, greater clarity of current measures, more knowledge of current measures, more social norms, more normative OOL, and greater PJ is associated with more compliance. We found a negative correlation between compliance and (i) opportunity to violate ( $r=-.10)$, (ii) impulsivity $(r=-.10)$, and (iii) non-normative OOL $(r=-.11)$. This suggests that more opportunity to violate, more impulsivity and more non-normative OOL is associated with less compliance. 
Table 5.

Kendall's tau correlations of control variables $(N=568)$.

\begin{tabular}{|c|c|c|c|c|c|c|c|c|c|c|c|c|c|}
\hline & $\stackrel{8}{\&}$ & $\begin{array}{l}\frac{\bar{\theta}}{\overline{0}} \\
\stackrel{0}{0}\end{array}$ & 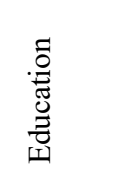 & 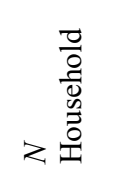 & 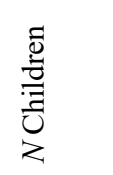 & 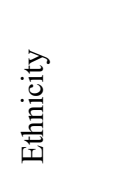 & 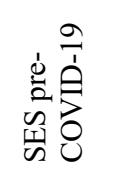 & 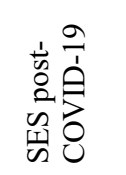 & 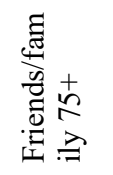 & 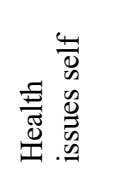 & 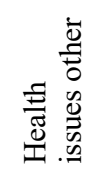 & 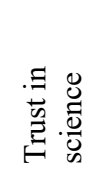 & 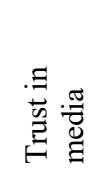 \\
\hline Gender & .029 & & & & & & & & & & & & \\
\hline Education & $.424 * *$ & $.088^{*}$ & & & & & & & & & & & \\
\hline$N$ Household & $-.251 * *$ & $-.086^{*}$ & $-.212 * *$ & & & & & & & & & & \\
\hline$N$ Children & $.308^{* *}$ & -.061 & $.132 * *$ & $.260 * *$ & & & & & & & & & \\
\hline Ethnicity & $.100 * *$ & $-.115^{* *}$ & .006 & -.010 & .038 & & & & & & & & \\
\hline SES pre-COVID-19 & .025 & $-.124 * *$ & $.112 * *$ & $.092 * *$ & $.127 * *$ & $.111 * *$ & & & & & & & \\
\hline SES post-COVID-19 & .009 & $-.138 * *$ & $.086^{*}$ & $.078^{*}$ & $.116^{* *}$ & $.116^{* *}$ & $.779 * *$ & & & & & & \\
\hline Friends/family $75+$ & .016 & -.056 & -.029 & .064 & .073 & $.210^{* *}$ & $.104 *$ & $.117^{* *}$ & & & & & \\
\hline Health issues self & .064 & .068 & .022 & $-.112 * *$ & .047 & -.022 & $-.117^{* *}$ & $-.103^{* *}$ & .038 & & & & \\
\hline Health issues other & -.066 & $.131^{* *}$ & $.101^{* *}$ & -.028 & .026 & .066 & .032 & .026 & $.176^{* *}$ & $.141^{* *}$ & & & \\
\hline Trust in science & -.025 & -.033 & $.073 *$ & -.011 & -.047 & $.102 * *$ & .055 & .054 & .065 & -.018 & .079 & & \\
\hline Trust in media & $.079 *$ & -.016 & $.070^{*}$ & -.041 & .055 & $.092 *$ & .085 & $.087^{*}$ & .058 & .009 & .068 & $.264 *$ & \\
\hline Compliance & $.073 *$ & $.128 * *$ & .039 & $-.092 * *$ & .043 & -.062 & -.015 & .004 & -.030 & $.080 *$ & $.073 *$ & $.083 *$ & .024 \\
\hline
\end{tabular}

Note. ${ }^{*}$ - Correlation is significant at the .05 level. ${ }^{* *}-$ Correlation is significant at the .01 level. Ethnicity $-N=556$ 
Table 6.

Kendall's tau correlations of independent variables $(N=568)$.

\begin{tabular}{|c|c|c|c|c|c|c|c|c|c|c|c|c|c|c|c|c|c|}
\hline & 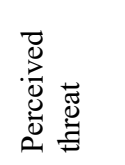 & 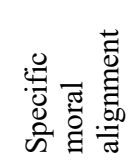 & 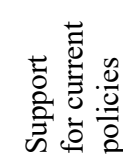 & 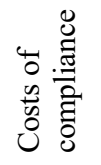 & 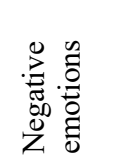 & 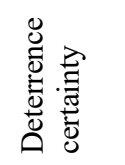 & 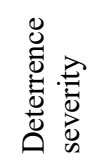 & 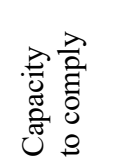 & 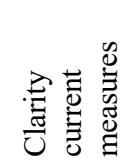 & $\begin{array}{l}\frac{80}{2} \\
\frac{0}{3} \\
0 \\
\vdots \\
0\end{array}$ & 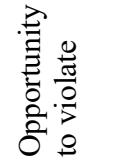 & 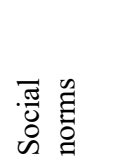 & 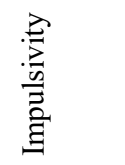 & 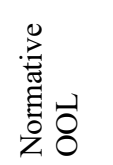 & ๖. & $\vec{a}$ & 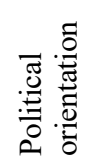 \\
\hline $\begin{array}{l}\text { Specific } \\
\text { moral alignment }\end{array}$ & $.359 * *$ & & & & & & & & & & & & & & & & \\
\hline $\begin{array}{l}\text { Support for } \\
\text { current policies }\end{array}$ & .009 & .003 & & & & & & & & & & & & & & & \\
\hline $\begin{array}{l}\text { Costs } \\
\text { of compliance }\end{array}$ & .076 & .007 & -.048 & & & & & & & & & & & & & & \\
\hline $\begin{array}{l}\text { Negative } \\
\text { emotions }\end{array}$ & $.191 * *$ & .053 & $-.076^{*}$ & $.209 * *$ & & & & & & & & & & & & & \\
\hline $\begin{array}{l}\text { Deterrence } \\
\text { certainty }\end{array}$ & $.068 *$ & .022 & $.076^{*}$ & .051 & .018 & & & & & & & & & & & & \\
\hline $\begin{array}{l}\text { Deterrence } \\
\text { severity }\end{array}$ & -.056 & .056 & -.019 & -.032 & $-.067 *$ & $-.085^{* *}$ & & & & & & & & & & & \\
\hline $\begin{array}{l}\text { Capacity } \\
\text { to comply }\end{array}$ & $.122 * *$ & $.294 * *$ & .046 & .011 & .035 & -.007 & .035 & & & & & & & & & & \\
\hline $\begin{array}{l}\text { Clarity } \\
\text { current measures }\end{array}$ & $.087 * *$ & $.113 * *$ & $.343 * *$ & -.044 & $-.066^{*}$ & $.109 * *$ & .046 & $.107 * *$ & & & & & & & & & \\
\hline Knowledge & $.171 * *$ & $.197 * *$ & -.007 & .034 & .054 & $.074 *$ & -.012 & $.156^{* *}$ & $.142 * *$ & & & & & & & & \\
\hline $\begin{array}{l}\text { Opportunity } \\
\text { to violate }\end{array}$ & $-.149^{* *}$ & $-.098^{* *}$ & .011 & -.041 & $-.082 *$ & $-.148^{* *}$ & .026 & -.033 & -.057 & $-.103^{* *}$ & & & & & & & \\
\hline Social norms & -.022 & $.083 *$ & $.137 * *$ & -.079 & -.060 & .020 & .015 & $.171^{* *}$ & $.129 * *$ & .020 & .011 & & & & & & \\
\hline Impulsivity & .005 & -.009 & .003 & .000 & $.081 * *$ & -.054 & .031 & -.026 & -.041 & .037 & -.053 & .003 & & & & & \\
\hline Normative OOL & $.218^{* *}$ & $.163 * *$ & $.072 *$ & .005 & $.077 *$ & .060 & .000 & $.103 * *$ & $.134 * *$ & $.159 * *$ & $-.082 * *$ & .059 & $-.135^{* *}$ & & & & \\
\hline $\begin{array}{l}\text { Non-normative } \\
\text { OOL }\end{array}$ & -.064 & $-.133 * *$ & -.042 & .034 & .046 & $.065 *$ & $-.068 *$ & $-.132 * *$ & -.043 & .060 & $-.066^{*}$ & $-.122 * *$ & $.126^{* *}$ & $-.068^{*}$ & & & \\
\hline PJ & .031 & $.106 * *$ & $.161 * *$ & -.027 & $-.074 *$ & .040 & -.002 & $.132 * *$ & $.178^{* *}$ & .052 & -.044 & $.157 * *$ & -.037 & $.186^{* *}$ & $-.141 * *$ & & \\
\hline $\begin{array}{l}\text { Political } \\
\text { orientation }\end{array}$ & -.037 & -.052 & -.020 & -.018 & $-.141^{* *}$ & .018 & -.020 & -.068 & .011 & .032 & .054 & $-.079 *$ & $.071 *$ & .038 & $.128 * *$ & .038 & \\
\hline Compliance & $.234 * *$ & $.370 * *$ & -.049 & .044 & $.069 *$ & .002 & .040 & $.292 * *$ & $.075^{*}$ & $.243 * *$ & $-.104 * *$ & $.071 *$ & $-.096 * *$ & $.190 * *$ & $-.111 * *$ & $.081 * *$ & -.058 \\
\hline
\end{tabular}

Note. ${ }^{*}$ - Correlation is significant at the .05 level. ${ }^{* *}-$ Correlation is significant at the .01 level. Political orientation $-N=503$. 


\section{Regression analysis}

We performed a series of ordinary least-squares regressions using the compliance measure as a dependent variable. For each predictor or subscale, a separate regression model was estimated utilizing a comprehensive set of control variables that were significantly correlated with compliance (Table 2), including: age, gender, number of people in direct household, having health issues that put you at-risk, knowing others with health issues that put them at-risk, and trust in science. Regressions were adjusted for heteroscedasticity using Huber/White robust standard error estimation. Table 7 shows the results of the OLS regressions.

\section{Table 7.}

\begin{tabular}{|c|c|c|c|}
\hline & B & SE & RSq \\
\hline \multicolumn{4}{|l|}{ Substantive moral support } \\
\hline Perceived threat & $.17 * *$ & .03 & .13 \\
\hline Moral belief & $.22 * *$ & .04 & .17 \\
\hline Support for current policies & -.03 & .03 & .07 \\
\hline Cost of compliance & .05 & .02 & .07 \\
\hline Negative emotions & .03 & .03 & .07 \\
\hline \multicolumn{4}{|l|}{ Deterrence } \\
\hline Certainty & .02 & .02 & .07 \\
\hline Severity & .04 & .03 & .07 \\
\hline \multicolumn{4}{|l|}{ Capacity to comply } \\
\hline Practical capacity & $.19 * *$ & .03 & .15 \\
\hline Clarity of current measures & $.03 *$ & .02 & .08 \\
\hline Knowledge & $.13 * *$ & .02 & .16 \\
\hline Opportunity to violate & $-.09 * *$ & .02 & .09 \\
\hline Impulsivity & $-.11 *$ & .04 & .09 \\
\hline Descriptive social norms & .04 & .03 & .07 \\
\hline \multicolumn{4}{|l|}{ OOL } \\
\hline Normative $O O L$ & $.07 * *$ & .02 & .10 \\
\hline Non-normative $O O L$ & -.03 & .03 & .07 \\
\hline PJ & .05 & .03 & .07 \\
\hline Political orientation & -.01 & .04 & .05 \\
\hline
\end{tabular}

The data show that several independent variables were significantly associated with compliance. We found positive, significant associations with compliance for perceived threat, moral belief, practical capacity, clarity of current measures, knowledge, and normative OOL. We found negative, significant associations with compliance for opportunity to violate, and 
impulsivity. For all other independent variables, no significant associations with compliance were observed.

To complement these separate regression models, we also conducted a series of stepwise regressions, in which multiple predictors were included in the same model (see table 8). This approach allows us to examine whether the associations with compliance remained when taking into account the effects of other independent variables. For these models, collinearity statistics indicated no issues with multicollinearity (all VIFs $\leq 1.44$; all tolerances $\geq .69$ ).

In the first step (model 0), we included only the control variables that significantly correlated with compliance (see Table 6). Results indicate that gender and trust in science showed significant associations with compliance, such that women and people that have more trust in science show greater compliance with COVID-19 mitigation measures. Age, number of members of direct household, personal health issues, and health issues of others were not related to compliance.

In model 1, we added the measures of substantive moral support (perceived threat, specific moral alignment, support for current policies), costs of compliance (costs of compliance and negative emotions) and impulsivity. Results indicate that perceived threat, specific moral alignment and impulsivity showed significant associations with compliance, such that participants who perceived more threat of the COVID-19 virus for themselves and others, who more strongly believed people should follow the COVID-19 mitigation measures, and who were less impulsive, showed greater compliance with the COVID-19 mitigation measures. Relative to model 0 , the percentage of explained variance in compliance increased from $7 \%$ to $21 \%$. Support for current policies, costs of compliance and negative emotions were unrelated to compliance.

In model 2, we added the measures of deterrence (certainty and severity) and descriptive social norms. Results indicate that descriptive social norms were significantly associated with 
compliance, such that people who reported more compliant descriptive social norms showed greater compliance. Relative to model 2 , the percentage of explained variance in compliance increased from $21 \%$ to $23 \%$. Deterrence was unrelated to compliance.

In model 3, we included the measures of capacity to comply (practical capacity, clarity of measures, knowledge) and opportunity to violate. Results indicate that practical capacity to comply, knowledge of measures, and the opportunity to violate were significantly associated with compliance, such that people who had greater ability to comply, who had more knowledge of the measures, and had less opportunity to violate, showed greater compliance with the COVID-19 mitigation measures. Relative to model 2, the percentage of explained variance increased from $23 \%$ to $32 \%$. Clarity of the current measures was not associated with compliance.

In model 4, we added the measures of OOL (normative OOL, non-normative OOL, PJ). Results indicated that none of these measures were associated with compliance. Relative to model 3, the percentage of explained variance did not change.

Last, in model 5, we added the measure of political orientation. The results indicated that political orientation was not associated with compliance. Relative to model 3 and 4, the percentage of explained variance did not change. 
Table 8.

Step-wise regression models of compliance with $N=568$

\begin{tabular}{|c|c|c|c|c|c|c|}
\hline & $\begin{array}{l}\text { Model } 0 . \\
\text { Baseline } \\
\text { model } \\
\text { (controls } \\
\text { only) }\end{array}$ & $\begin{array}{l}\text { Model } 1 \\
+ \text { Substantive } \\
\text { moral support, } \\
\text { Costs of } \\
\text { compliance, } \\
\text { impulsivity }\end{array}$ & $\begin{array}{l}\text { + Deterrence, } \\
\text { Social norms }\end{array}$ & $\begin{array}{l}\text { Model } 3 \\
+ \text { Capacity to } \\
\text { comply, } \\
\text { opportunity to } \\
\text { violate }\end{array}$ & $\begin{array}{l}+ \text { Obligation } \\
\text { to obey the } \\
\text { law }\end{array}$ & $\begin{array}{l}+ \text { Political } \\
\text { orientation }\end{array}$ \\
\hline & $\mathrm{B}(\mathrm{SE})$ & $\mathrm{B}(\mathrm{SE})$ & $\mathrm{B}(\mathrm{SE})$ & $\mathrm{B}(\mathrm{SE})$ & $\mathrm{B}(\mathrm{SE})$ & $\mathrm{B}(\mathrm{SE})$ \\
\hline Age & $.01(.00)$ & $.00(.00)$ & $.00(.00)$ & $.00(.00)$ & $.00(.00)$ & $.00(.00)$ \\
\hline \multicolumn{7}{|l|}{ Gender } \\
\hline i female & $.20 * *(.06)$ & $.09(.06)$ & $.09(.06)$ & $.12 *(.06)$ & $.11(.06)$ & $.08(.06)$ \\
\hline ii other & $-.02(.29)$ & $-.19(.27)$ & $-.22(.27)$ & $-.28(.27)$ & $-.29(.27)$ & $-.32(.26)$ \\
\hline$N$ household & $-.02(.02)$ & $-.03(.02)$ & $-.03(.02)$ & $-.02(.02)$ & $-.02(.02)$ & $-.02(.02)$ \\
\hline Health (self) & $.14(.08)$ & $.07(.08)$ & $.08(.08)$ & $.08(.07)$ & $.08(.08)$ & $.10(.08)$ \\
\hline Health (other) & $.05(.07)$ & $.04(.07)$ & $.03(.07)$ & $.07(.06)$ & $.07(.06)$ & $.07(.07)$ \\
\hline $\begin{array}{l}\text { Trust } \\
\text { in science }\end{array}$ & $.15 * * *(.04)$ & $.08(.05)$ & $.07(.05)$ & $.07(.04)$ & $.06(.05)$ & $.06(.05)$ \\
\hline Perceived threat & & $.10 * *(.03)$ & $.11 * * *(.03)$ & $.07(.03)$ & $.07 *(.03)$ & $.07 *(.03)$ \\
\hline $\begin{array}{l}\text { Specific moral } \\
\text { alignment }\end{array}$ & & $.19 * * *(.04)$ & $.18 * * *(.04)$ & $.13 * *(.04)$ & $.13 * *(.04)$ & $.14 * * *(.04)$ \\
\hline $\begin{array}{l}\text { Support current } \\
\text { measures }\end{array}$ & & $-.03(.03)$ & $-.04(.03)$ & $-.05(.03)$ & $-.05(.03)$ & $-.05(.03)$ \\
\hline Cost of compliance & & $.03(.02)$ & $.03(.02)$ & $.03(.02)$ & $.03(.02)$ & $.04(.02)$ \\
\hline Negative emotions & & $.00(.03)$ & $.01(.03)$ & $.00(.03)$ & $.00(.03)$ & $.02(.03)$ \\
\hline Impulsivity & & $-.13^{* *}(.04)$ & $-.14 * *(.04)$ & $-.13^{* *}(.04)$ & $-.13^{* *}(.04)$ & $-.14 * *(.04)$ \\
\hline Deterrence certainty & & & $-.00(.02)$ & $-.02(.02)$ & $-.02(.02)$ & $-.02(.02)$ \\
\hline Deterrence severity & & & $.04(.02)$ & $.04(.02)$ & $.04(.02)$ & $.05(.03)$ \\
\hline $\begin{array}{l}\text { Descriptive social } \\
\text { norms }\end{array}$ & & & $.06 *(.03)$ & $.04(.02)$ & $.04(.03)$ & $.04(.03)$ \\
\hline $\begin{array}{l}\text { Practical capacity to } \\
\text { comply }\end{array}$ & & & & $.12 * * *(.03)$ & $.12 * * *(.03)$ & $.12 * * *(.03)$ \\
\hline Clarity of measures & & & & $.01(.02)$ & $.02(.02)$ & $.02(.03)$ \\
\hline Knowledge & & & & $.08^{* * *}(.02)$ & $.08 * * *(.02)$ & $.08 * * *(.01)$ \\
\hline $\begin{array}{l}\text { Opportunity to } \\
\text { violate }\end{array}$ & & & & $-.06 *(.02)$ & $-.06 *(.02)$ & $-.07 * *(.03)$ \\
\hline NOOL & & & & & $.02(.02)$ & $.00(.02)$ \\
\hline NNOOL & & & & & $-.01(.02)$ & $-.02(.03)$ \\
\hline $\mathrm{PJ}$ & & & & & $-.01(.03)$ & $-.02(.03)$ \\
\hline Political orientation & & & & & & $.02(.04)$ \\
\hline Rsq & .07 & .21 & .23 & .32 & .32 & .32 \\
\hline Rsq change & & .14 & .02 & .09 & 0 & 0 \\
\hline
\end{tabular}

Note. * - Correlation is significant at the .05 level. ** - Correlation is significant at the .01 level. $* * *$ - Correlation is significant at the .001 level. Model $5-N=503$

\section{Discussion}

This study had two main purposes. First, we investigated to what extent people residing in the Netherlands have complied with the measures taken to slow the spread of COVID-19 virus. Overall, we found relatively high self-reported compliance with coronavirus mitigation measures in the Netherlands. This is generally in line with the previous Dutch study of I\&O Research and Universiteit Twente (2020). In their study, they found that $99 \%$ of the people kept a safe distance of 1.5 meters of others, and that $87 \%$ stayed at home if they did not feel well. 
However, our study does not allow us to analyze any change in behavior, because we only used one moment of measurement.

Second, we analyzed why people complied with the measures, based on insights from prior insights on compliance and rule breaking. We found mixed results about whether overall substantive moral support for the measures was related to compliant behavior. On one hand, we found a positive association between reported compliance and both whether people feared the COVID-19 virus and whether people morally believed that measures should be followed. On the other hand, counterintuitively, we did not find an association between compliance and whether people generally supported the measures. As such, personal fear of the virus and specific moral beliefs about compliance with the measures played a significant role in behavioral responses to the measures.

We expected that greater costs of compliance would predict less compliance; as the higher costs of compliance the less likely people will rationally decide to obey the measures (Donovan and Blake 1992, Paternoster and Simpson 1993). However, the results showed no relation between costs of compliance and compliant behavior. In addition, we expected that more negative emotions would predict less compliant behavior (Agnew 1992, 2007, Agnew et al. 2002, Agnew and White 1992, Botchkovar, Tittle, and Antonaccio 2009, Piquero and Sealock 2004). We found no relation between negative emotions and compliance. A possible explanation could be that at the time this survey was conducted, the measures were in place only for a relatively short time and that the costs of compliance had not strongly materialized yet. It may well be that, as the measures stay in place longer, or should they be reinstituted in the case of a second wave, the costs and negative emotions may come to negatively affect compliance as strain theory suggests.

We investigated whether the deterrent effect of measures is associated with compliance. We found no relation for severity of deterrence with compliance, which is not entirely 
surprising, because existing data shows inconclusive evidence that stricter punishment alone can deter offending (Nagin 2013, Nagin, Cullen, and Jonson 2009, Nagin and Pepper 2012, Simpson et al. 2014). In the deterrence literature, what matters most is certainty of punishment. However, we found no relation between certainty of punishment and compliance. A possible reason could be that certainty of detection and punishment for violating COVID-19 mitigation measures in the Netherlands does not meet the minimum threshold. Research shows that below a minimum threshold, punishment will not deter (Brown 1978, Chamlin 1991). Achieving a minimum threshold for the certainty of detection could be challenging in the Netherlands where people are still allowed to go outside without an official statement, as opposed to for example in France. Since the strict COVID-19 mitigation measures starting on March 17, French police conducted 11.8 million checks in one month, and gave 700.000 fines during these checks. ${ }^{\text {xvii }}$ As a comparison, the Dutch police gave around 5.500 fines for violating COVID-19 measures from the end of March until April 23. ${ }^{\text {xxviii }}$ Nevertheless, even without a significant association between deterrence and compliance, people reported relatively high compliance. It seems that compliance in the Netherlands is voluntary rather than enforced. Thus, this is in line with the principles of the intelligent lockdown that emphasize self-discipline and moral responsibility.

Overall, we found that two core elements of people's capacity to comply were associated with compliance. The results showed a positive association between people's ability to comply and compliance, meaning that people who are less able to comply with the measures (e.g., less able to work from home or to keep a safe distance from others) are indeed less likely to keep social distance and stay at home. We also found that people with more knowledge about the measures show more compliant behavior, which is in line with previous research (Darley, Carlsmith, and Robinson 2001, Kim 1999, van Rooij and Sokol 2021 (Forthcoming)). Nonetheless, we did not find a relation between clarity of the measures and compliance, as we expected based on Feldman and Teichman (2009). As such, the ability to comply with the 
measures and knowledge about the measures played a significant role in the behavioral responses to the measures.

The data further showed that people with more opportunity to violate the measures showed less compliant behavior. This finding is in line with the expectations (Clarke 2003, 2005, Cohen and Felson 1979, Osgood et al. 1996, Spano and Freilich 2009). This means that people who can, for example, still visit people outside of their household, or go outside for nonessential activities are more likely to violate the measures. In reality, many beaches in the Netherlands were busy during the first weekend after the measures were implemented because people still had the opportunity to go there. ${ }^{x i x}$ After closing the roads to the beaches, and therefore taking away the opportunity, beaches were almost empty the week after. ${ }^{\mathrm{xxx}}$ When considered alongside the deterrence findings, this provides clear guidance to policymakers and practitioners; deterrence threats of fines, fees, and punishments may have little impact, whereas physically closing locations and making violating restrictions more difficult appears far more impactful for enhancing compliance.

The data further shows that impulsivity is associated with noncompliance. This is in line with the expectations based on the study of self-control in offending behavior (Gottfredson and Hirschi 1990, Pratt and Cullen 2000, 2005, Pratt and Llouyd 2021 (Forthcoming), Vazsonyi, Mikuška, and Kelley 2017). It means that people who reported to be more impulsive are less likely to comply with the measures to mitigate COVID-19. Although the intelligent lockdown asks people to maintain self-discipline, these findings show that this will not be possible for everyone equally.

We found a positive association between descriptive social norms and compliance, meaning that the more people see others comply, the more likely they are to keep social distance and to stay at home. Previous research about social norms has shown that social norms can have a powerful influence on compliance (Cialdini et al. 2006, Cialdini and Trost 1998, Goldstein, 
Cialdini, and Griskevicius 2008, Schultz et al. 2007). In a short period of time, we see a fundamental change in descriptive social norms. Suddenly most people stay at home, refrain from meeting people outside of their household and keep a safe distance. People who don't comply can expect anger directed toward them on social media about their behavior. ${ }^{\text {xxxi }}$ It seems that the Dutch Government has been smart in emphasizing the positive social norms and in subsequent press conferences stating how many people are complying with the measures, and how we are moving into a normal situation of social distancing with the 1.5 meter society. ${ }^{\mathrm{xx} x i i}$

We found no association between obligation to obey the law and compliance, or with procedural justice and compliance. Similar, we found no association between political orientation and compliance. A possible explanation could be that in times of crisis, people support their leader regardless of political ideology, also known as 'rally around the flag' (Mueller 1970, Mueller 1973). Dutch polls show that eight of out ten people support the approach of the Government to mitigate the virus, and that people show more trust in both Premier Rutte and the Government in March as compared to February. ${ }^{\text {xxxiii }}$ Furthermore, both members of the Dutch Cabinet and leaders of the opposition parties have emphasized that the approach of this crisis is unrelated to political ideology and that the right approach should be based on advice of experts and scientists. ${ }^{\text {xxiv }}$

\section{Limitations}

Some limitations of this study must be acknowledged. As a first limitation, we used selfreported compliance data that may be subjected to response biases, such as imperfect recall or social desirability bias (Bauhoff 2011, Van de Mortel 2008). However, the finding of high selfreported compliance is in line with objective data from Google COVID19 Community Mobility, ${ }^{\mathrm{xxx}}$ that shows large drops in human activity trends compared to data from before the pandemic in retail and recreation, use of transit stations, and visits to workplaces. Also, existing 
research shows that there can be strong concordance between self-reported and objective compliance measures when surveys are utilized (Bachmann et al. 1999, Dieltjens et al. 2013, Garber et al. 2004, Rauscher et al. 1993, Ridgers et al. 2012). More specifically, a recent study found that social desirability bias did not inflate the estimates of compliance with COVID-19 measures in online surveys (Larsen, Petersen, and Nyrup 2020). However, it is still possible that there is a sampling bias in our study. While our sample showed diversity in terms of demographic variables (age, gender, ethnicity, political orientation and geographical locations), we cannot claim to have a full representative statement for the Netherlands. It might thus be possible that there are unobserved differences that have affected study outcomes (i.e., unobserved variable bias). Finally, in the analyses, we limited ourselves to multivariate regressions for all controls and independent variables. We have not yet conducted interactions or models of sets of variables to gain more insights about how different variables may mediate others.

\section{Conclusion}

The 'intelligent lockdown' in the Netherlands can be seen as an appeal to citizens' own responsibility and sense of self-discipline. Citizens in the Netherlands have been allowed more freedom to leave their house and authorities have focused less on repression and more on moral appeals and messages stressing positive behavior. Yet, in reality the intelligent lockdown also did restrict freedom, by closing public venues, restricting parking at parks and beaches, and with shops limiting the number of customers, resulting in less freedom and less choice.

The results from this study show that the principles of the intelligent lockdown are mostly in line with what we found has influenced compliance at the time of our study. We indeed found that deterrence was not at play in compliance, and as such that a strategy to 
achieve compliance through punishment and repression would not have been effective. We found that people's intrinsic motivation was key and that compliance originated from an overall fear of disease, a moral support for compliance with the measures and a social view that compliance is normal. At the same time, we see that such an intrinsic motivation did not operate alone. People also complied because they were able to do so and because they had less opportunity to break the rules. Reducing such opportunities is particularly important, as not everyone has the self-discipline that the authorities ask for, and people with lower selfcontrol are more likely to break the rules.

Our data only allow us to assess what influenced compliance on April 7-14. We can only speculate what will happen in the upcoming period of time. As people see the number of infections and deaths decrease as a result of the initial measures, it is possible that people start to fear the virus less, and they might have less substantive moral support for compliance with the measures. We expect that the longer people have to maintain social distance and stay at home, the costs of compliance will increase, for example by losing income or even jobs. This could undermine their capacity to comply, which could lead to less compliant behavior. We speculate that if the costs of compliance increase, negative emotions will also increase, enabling people to cope through offending based on strain theory (Agnew 1992, 2007, Agnew et al. 2002, Agnew and White 1992, Baron 2004, Botchkovar, Tittle, and Antonaccio 2009, Piquero and Sealock 2004). Under the pressure of the rising costs, authorities will likely lift some of the current restrictions (e.g., authorities have already decided to open up primary schools $\left.^{\mathrm{xxxvi}}\right)$. By doing so, opportunity to violate the measures will increase, which could have negative consequences for compliance. Once more people start to violate the rules because of the loosened restrictions, social norms will start to shift and non-compliance may normalize. This could cause a change in factors that influence compliance with the measures. 
Without a vaccine, social distancing measures may be necessary until 2022 to prevent a second outbreak from happening (Kissler et al. 2020). To continue the intelligent lockdown, it is therefore crucial that authorities maintain balance between ensuring freedom where needed and possible, while maintaining sufficient sources of influence that keep people from resorting back to their pre-corona lives en masse before it is safe to do so. We intend to continue our study in several more waves in the coming weeks to track how compliance develops as circumstances change, to help ensure that authorities take the right steps to continue to mitigate COVID-19. 


\section{References}

Adler, Nancy E, Elissa S Epel, Grace Castellazzo, and Jeannette R Ickovics. 2000. "Relationship of subjective and objective social status with psychological and physiological functioning: Preliminary data in healthy, White women." Health psychology 19 (6):586. doi: 10.1037/02786133.19.6.586.

Agnew, Robert. 1992. "Foundation for a general strain theory of crime and delinquency." Criminology 30 (1):47-88. doi: 10.1111/j.1745-9125.1992.tb01093.x.

Agnew, Robert. 2007. Pressured into crime: An overview of general strain theory: Oxford University Press USA.

Agnew, Robert, Timothy Brezina, John Paul Wright, and Francis T Cullen. 2002. "Strain, personality traits, and delinquency: Extending general strain theory." Criminology 40 (1):43-72. doi: 10.1111/j.1745-9125.2002.tb00949.x.

Agnew, Robert, and Helene Raskin White. 1992. "An empirical test of general strain theory." Criminology 30 (4):475-500. doi: 10.1111/j.1745-9125.1992.tb01113.x.

Anderson, Roy M, Hans Heesterbeek, Don Klinkenberg, and T Déirdre Hollingsworth. 2020. "How will country-based mitigation measures influence the course of the COVID-19 epidemic?" The Lancet 395 (10228):931-934. doi: 10.1016/ S0140-6736(20)30567-5.

Apel, Robert. 2013. "Sanctions, perceptions, and crime: Implications for criminal deterrence." Journal of quantitative criminology 29 (1):67-101. doi: 10.1007/s10940-012-9170-1.

Bachmann, Laura H, Joan Stephens, Charity M Richey, and EDWARD W HOOK III. 1999. "Measured versus self-reported compliance with doxycycline therapy for chlamydia-associated syndromes: high therapeutic success rates despite poor compliance." Sexually transmitted diseases 26 (5):272-278.

Baker, Thomas, and Jacinta M Gau. 2018. "Female offenders' perceptions of police procedural justice and their obligation to obey the law." Crime \& Delinquency 64 (6):758-781. doi: 10.1177/0011128717719418.

Baron, Stephen W. 2004. "General strain, street youth and crime: A test of Agnew's revised theory." Criminology 42 (2):457-484. doi: 10.1111/j.1745-9125.2004.tb00526.x.

Bauhoff, Sebastian. 2011. "Systematic self-report bias in health data: impact on estimating crosssectional and treatment effects." Health Services and Outcomes Research Methodology 11 (12):44-53. doi: 10.1007/s10742-011-0069-3.

Baum, Matthew A, and Tim Groeling. 2008. "New media and the polarization of American political discourse." Political Communication 25 (4):345-365. doi: 10.1080/10584600802426965.

Becker, Gary S. 1968. "Crime and punishment: An economic approach." Journal of Political Economy $76: 169-217$.

Botchkovar, Ekaterina V, Charles R Tittle, and Olena Antonaccio. 2009. "General strain theory: Additional evidence using cross-cultural data." Criminology 47 (1):131-176. doi: 10.1111/j.1745-9125.2009.00141.x.

Braga, Anthony A, David Weisburd, and Brandon Turchan. 2019. "Focused deterrence strategies effects on crime: A systematic review." Campbell Systematic Reviews 15 (3):e1051. doi: $10.1002 / \mathrm{cl} 2.1051$.

Briscese, Guglielmo, Nicola Lacetera, Mario Macis, and Mirco Tonin. 2020. Compliance with COVID19 Social-Distancing Measures in Italy: The Role of Expectations and Duration. National Bureau of Economic Research.

Brown, Don W. 1978. "Arrest rates and crime rates: when does a tipping effect occur?" Social Forces 57 (2):671-682. doi: 10.1093/sf/57.2.671. 
Chamlin, Mitchell B. 1991. "A longitudinal analysis of the arrest-crime relationship: A further examination of the tipping effect." Justice Quarterly 8 (2):187-199. doi: 10.1080/07418829100090991.

Chen, Simiao, Juntao Yang, Weizhong Yang, Chen Wang, and Till Bärnighausen. 2020. "COVID-19 control in China during mass population movements at New Year." The Lancet 395 (10226):764-766. doi: 10.1016/S0140-6736(20)30421-9.

Cialdini, Robert B, Linda J Demaine, Brad J Sagarin, Daniel W Barrett, Kelton Rhoads, and Patricia L Winter. 2006. "Managing social norms for persuasive impact." Social influence 1 (1):3-15.

Cialdini, Robert B, and Melanie R Trost. 1998. "Social influence: Social norms, conformity and compliance." doi: 10.1146/annurev.psych.55.090902.142015.

Clarke, Ronald VG. 2003. "'Situational'Crime Prevention." Crime: Critical Concepts in Sociology 1 (136):276-88.

Clarke, Ronald VG. 2005. "Seven misconceptions of situational crime prevention." In Handbook of crime prevention and community safety, edited by Nick Telley. New York, NY: Routledge.

Cohen, Lawrence E, and Marcus Felson. 1979. "Social change and crime rate trends: A routine activity approach." American sociological review:588-608. doi: 10.2307/2094589.

Darley, John M, Kevin M Carlsmith, and Paul H Robinson. 2001. "The ex ante function of the criminal law." Law \& Soc'y Rev. 35:165.

Decker, Scott, Richard Wright, and Robert Logie. 1993. "Perceptual deterrence among active residential burglars: A research note." Criminology 31 (1):135-147. doi: 10.1111/j.17459125.1993.tb01125.x.

Dieltjens, Marijke, Marc J Braem, Anneclaire VMT Vroegop, Kristien Wouters, Johan A Verbraecken, Wilfried A De Backer, Paul H Van de Heyning, and Olivier M Vanderveken. 2013. "Objectively measured vs self-reported compliance during oral appliance therapy for sleep-disordered breathing." Chest 144 (5):1495-1502. doi: 10.1378/chest.13-0613.

Donovan, Jenny L, and David R Blake. 1992. "Patient non-compliance: deviance or reasoned decisionmaking?" Social science \& medicine 34 (5):507-513. doi: 10.1016/0277-9536(92)90206-6.

Edwards, Alison. 2014. "English in the Netherlands: Functions, Forms and Attitudes." PhD, Department of Theoretical and Applied Linguistics University of Cambridge.

Estévez, Estefanía, and Nicholas P Emler. 2010. "A structural modelling approach to predict adolescent offending behaviour from family, school and community factors." European Journal on Criminal Policy and Research 16 (4):207-220. doi: 10.1007/s10610-010-9128-5.

Feldman, Yuval. 2018. The law of good people: Challenging states' ability to regulate human behavior. Cambridge, UK: Cambridge University Press

Feldman, Yuval, and Doron Teichman. 2009. "Are all legal probabilities created equal." NYUL Rev. 84:980.

Fetzer, Thiemo, Marc Witte, Lukas Hensel, Jon Jachimowicz, Johannes Haushofer, Andriy Ivchenko, Stefano Caria, Elena Reutskaja, Christopher Roth, and Stefano Fiorin. 2020. "Global Behaviors and Perceptions in the COVID-19 Pandemic." PsyArXiv Preprint. doi: 10.31234/osf.io/3kfmh.

Fine, Adam D, Zachary Rowan, and Cortney Simmons. 2019. "Do politics Trump race in determining America's youths' perceptions of law enforcement?" Journal of Criminal Justice 61:48-57. doi: 10.1016/j.jcrimjus.2019.01.003.

Fine, Adam, April Thomas, Benjamin van Rooij, and Elizabeth Cauffman. 2020. "Age-Graded Differences and Parental Influences on Adolescents' Obligation to Obey the Law." Journal of Developmental and Life-Course Criminology:1-18. doi: 10.1007/s40865-020-00134-8.

Fine, Adam, Benjamin Van Rooij, Yuval Feldman, Shaul Shalvi, Eline Scheper, Margarita Leib, and Elizabeth Cauffman. 2016. "Rule orientation and behavior: Development and validation of a 
scale measuring individual acceptance of rule violation." Psychology, Public Policy, and Law 22 (3):314. doi: 10.1037/law0000096.

Fletcher, Richard, and Rasmus Kleis Nielsen. 2017. "Are news audiences increasingly fragmented? A cross-national comparative analysis of cross-platform news audience fragmentation and duplication." Journal of Communication 67 (4):476-498. doi: 10.1111/jcom.12315.

Friedman, Lawrence M. 2016. Impact: Harvard University Press.

Garber, Mathew C, David P Nau, Steven R Erickson, James E Aikens, and Joseph B Lawrence. 2004. "The concordance of self-report with other measures of medication adherence: a summary of the literature." Medical care:649-652.

Gates, Bill. 2020. "Responding to Covid-19-a once-in-a-century pandemic?" New England Journal of Medicine. doi: 10.1056/NEJMp2003762.

Gau, Jacinta M. 2014. "Procedural justice and police legitimacy: A test of measurement and structure." American Journal of Criminal Justice 39 (2):187-205. doi: 10.1007/s12103-013-9220-8.

Goldstein, Noah J, Robert B Cialdini, and Vladas Griskevicius. 2008. "A room with a viewpoint: Using social norms to motivate environmental conservation in hotels." Journal of consumer Research 35 (3):472-482. doi: 10.1086/586910.

Gottfredson, Michael R, and Travis Hirschi. 1990. A general theory of crime: Stanford University Press.

Grasmick, Harold G, and George J Bryjak. 1980. "The deterrent effect of perceived severity of punishment." Social forces 59 (2):471-491. doi: 10.1093/sf/59.2.471.

Harper, Craig A, Liam Satchell, Dean Fido, and Robert Latzman. 2020. "Functional fear predicts public health compliance in the COVID-19 pandemic." PsyArXiv Preprint. doi: 10.31234/osf.io/jkfu3.

Hasson, Yossi, Maya Tamir, Kea S Brahms, J Christopher Cohrs, and Eran Halperin. 2018. "Are liberals and conservatives equally motivated to feel empathy toward others?" Personality and Social Psychology Bulletin 44 (10):1449-1459. doi: 10.1177/0146167218769867.

I\&O Research, and Universiteit Twente. 2020. Rapport: Het Corona- en het eenzaamheidsvirus. Amsterdam: I\&O Research.

Kim, Pauline T. 1999. "Norms, learning, and law: Exploring the influences on workers' legal knowledge." U. Ill. L. Rev.:447.

Kissler, Stephen M, Christine Tedijanto, Edward Goldstein, Yonatan H Grad, and Marc Lipsitch. 2020. "Projecting the transmission dynamics of SARS-CoV-2 through the postpandemic period." Science. doi: 10.1126/science.abb5793.

Kushner Gadarian, Shana, Sara Wallace Goodman, and Thomas B Pepinsky. 2020. "Partisanship, health behavior, and policy attitudes in the early stages of the COVID-19 pandemic." SSRN Electron. doi: $10.2139 /$ ssrn. 3562796

Larsen, Martin Vinæs, Michael Bang Petersen, and Jacob Nyrup. 2020. "[Preprint] Do Survey Estimates of the Public's Compliance with COVID-19 Regulations Suffer from Social Desirability Bias?".

Lunn, Peter D, Cameron A Belton, Ciarán Lavin, Féidhlim P McGowan, Shane Timmons, and Deirdre A Robertson. 2020. "Using Behavioral Science to help fight the Coronavirus." Journal of Behavioral Public Administration 3 (1). doi: 10.30636/jbpa.31.147.

McCright, Aaron M, Katherine Dentzman, Meghan Charters, and Thomas Dietz. 2013. "The influence of political ideology on trust in science." Environmental Research Letters 8 (4):044029. doi: 10.1088/1748-9326/8/4/044029/meta.

Mueller, J. E. 1973. War, presidents and public opinion. New York, NY: John Wiley \& Sons.

Mueller, John E. 1970. "Presidential Popularity from Truman to Johnson 1." American Political Science Review 64 (1):18-34. doi: 10.2307/1955610.

Nagin, Daniel S. 2013. "Deterrence in the twenty-first century." Crime and justice 42 (1):199-263.

Nagin, Daniel S, Francis T Cullen, and Cheryl Lero Jonson. 2009. "Imprisonment and reoffending." Crime and justice 38 (1):115-200. 
Nagin, Daniel S, and John V Pepper, eds. 2012. Deterrence and the death penalty. Washington DC: National Academies Press.

Nagin, Daniel S, and Cody W Telep. 2017. "Procedural justice and legal compliance." Annual Review of Law and Social Science 13:5-28. doi: 10.1146/annurev-lawsocsci-110316-113310.

Oosterhoff, Benjamin, and C. Palmer. 2020. "Psychological correlates of news monitoring, social distancing, disinfecting, and hoarding behaviors among US adolescents during the COVID-19 pandemic." PsyArXiv Preprint. doi: 10.31234/osf.io/rpcy4.

Osgood, D Wayne, Janet K Wilson, Patrick M O'malley, Jerald G Bachman, and Lloyd D Johnston. 1996. "Routine activities and individual deviant behavior." American sociological review:635655. doi: $10.2307 / 2096397$.

Painter, Marcus, and Tian Qiu. 2020. "Political beliefs affect compliance with covid-19 social distancing orders." Available at SSRN 3569098.

Paternoster, Raymond, and Sally Simpson. 1993. "A rational choice theory of corporate crime." Routine activity and rational choice 5:37.

Pfattheicher, Stefan, Laila Nockur, Robert Böhm, Claudia Sassenrath, and Michael Bang Petersen. 2020. "The emotional path to action: Empathy promotes physical distancing during the COVID19 pandemic." PsyArXiv Preprint. doi: 10.31234/osf.io/y2cg5.

Piquero, Nicole Leeper, and Miriam D Sealock. 2004. "Gender and general strain theory: A preliminary test of Broidy and Agnew's gender/GST hypotheses." Justice quarterly 21 (1):125-158. doi: 10.1080/07418820400095761.

Plohl, Nejc, and Bojan Musil. 2020. "Modeling compliance with COVID-19 prevention guidelines: The critical role of trust in science." PsyArXiv Preprint. doi: 10.31234/osf.io/6a2cx.

Polinsky, Mitchell A., and Steven Shavell. 2000. "Public Enforcement of Law." In Encyclopedia of law and economics, Volume $V$. The economics of crime and litigation, edited by Boudewijn Bouckaert and Gerrit De Geest, 307-344. Cheltenham: Edward Elgar.

Posch, Krisztian, Jonathan Jackson, Ben Bradford, and Sarah Macqueen. 2020. "' Truly Free Consent"? Clarifying the Nature of Police Legitimacy using Causal Mediation Analysis." Journal of Experimental Criminology.

Pratt, Travis C, and Francis T Cullen. 2000. "The empirical status of Gottfredson and Hirschi's general theory of crime: A meta-analysis." Criminology 38 (3):931-964.

Pratt, Travis C, and Francis T Cullen. 2005. "Assessing macro-level predictors and theories of crime: A meta-analysis." Crime and justice 32:373-450. doi: 10.1086/655357.

Pratt, Travis C, and Kristin Llouyd. 2021 (Forthcoming). "Self-control and offending." In Cambridge Handbook of Compliance, edited by Benjamin van Rooij and Daniel D. Sokol. Cambridge, UK: Cambridge University Press.

Prior, Markus. 2013. "Media and political polarization." Annual Review of Political Science 16:101127. doi: 10.1146/annurev-polisci-100711-135242.

Rauscher, Helmuth, Dieter Formanek, Wolfgang Popp, and Hartmut Zwick. 1993. "Self-reported vs measured compliance with nasal CPAP for obstructive sleep apnea." Chest 103 (6):1675-1680. doi: 10.1378/chest.103.6.1675.

Reisig, Michael D, Jason Bratton, and Marc G Gertz. 2007. "The construct validity and refinement of process-based policing measures." Criminal justice and behavior 34 (8):1005-1028. doi: 10.1177/0093854807301275.

Ridgers, Nicola D, Anna Timperio, David Crawford, and Jo Salmon. 2012. "Validity of a brief selfreport instrument for assessing compliance with physical activity guidelines amongst adolescents." Journal of Science and Medicine in Sport 15 (2):136-141. doi: 10.1016/j.jsams.2011.09.003. 
Sailer, Michael, Matthias Stadler, Elouise Botes, Frank Fischer, and Samuel Greiff. 2020. "Science knowledge and trust in medicine affect individuals' behavior in pandemic crises." PsyArXiv Preprint. doi: 10.31234/osf.io/tmu8f.

Schultz, P Wesley, Jessica M Nolan, Robert B Cialdini, Noah J Goldstein, and Vladas Griskevicius. 2007. "The constructive, destructive, and reconstructive power of social norms." Psychological science 18 (5):429-434.

Shavell, Steven. 1991. "Specific versus general enforcement of law." Journal of political Economy 99 (5):1088-1108. doi: 10.1086/261790.

Simpson, Sally S, Melissa Rorie, Mariel Alper, Natalie Schell-Busey, William S Laufer, and N Craig Smith. 2014. "Corporate crime deterrence: A systematic review." Campbell systematic reviews 10 (1):1-105. doi: 10.4073/csr.2014.4.

Spano, Richard, and Joshua D Freilich. 2009. "An assessment of the empirical validity and conceptualization of individual level multivariate studies of lifestyle/routine activities theory published from 1995 to 2005." Journal of Criminal Justice 37 (3):305-314. doi: 10.1016/j.jcrimjus.2009.04.011.

Spohr, Dominic. 2017. "Fake news and ideological polarization: Filter bubbles and selective exposure on social media." Business Information Review 34 (3):150-160. doi: $10.1177 / 0266382117722446$.

Tankebe, Justice, Michael D Reisig, and Xia Wang. 2016. "A multidimensional model of police legitimacy: A cross-cultural assessment." Law and Human Behavior 40 (1):11. doi: 10.1037/lhb0000153.

Tyler, Tom R. 1997. "Procedural fairness and compliance with the law." Swiss Journal of Economics and Statistics 133:219-240.

Tyler, Tom R. 2006. Why people obey the law. Princeton: Princeton University Press.

Tyler, Tom R. 2017. "Procedural justice and policing: A rush to judgment?" Annual Review of Law and Social Science 13:29-53. doi: 10.1146/annurev-lawsocsci-110316-113318.

Van Bavel, Jay J, Paulo Boggio, Valerio Capraro, Aleksandra Cichocka, Mina Cikara, Molly Crockett, Alia Crum, Karen Douglas, James Druckman, and John Drury. 2020. "Using social and behavioural science to support COVID-19 pandemic response." PsyArXiv Preprint. doi: 10.31234/osf.io/y38m9.

Van de Mortel, Thea F. 2008. "Faking it: social desirability response bias in self-report research." Australian Journal of Advanced Nursing, The 25 (4):40.

van Rooij, Benjamin. 2021 (Forthcoming). "Do people know the law? Empirical evidence about legal knowledge and its implications for compliance." In Cambridge Handbook of Compliance, edited by Benjamin van Rooij and Daniel D. Sokol. Cambridge, UK: Cambridge University Press.

van Rooij, Benjamin, and Daniel D. Sokol, eds. 2021 (Forthcoming). Cambridge Handbook of Compliance. Cambridge, UK: Cambridge University Press.

Vazsonyi, Alexander T., Jakub Mikuška, and Erin L. Kelley. 2017. "It's time: A meta-analysis on the self-control-deviance link " Journal of Criminal Justice 48:48-63. doi: 10.1016/j.jcrimjus.2016.10.001.

Waldo, Gordon P, and Theodore G Chiricos. 1972. "Perceived penal sanction and self-reported criminality: A neglected approach to deterrence research." Social Problems 19 (4):522-540.

Walker, Patrick GT, Charles Whittaker, Oliver Watson, M Baguelin, KEC Ainslie, S Bhatia, S Bhatt, A Boonyasiri, O Boyd, and L Cattarino. 2020. "The global impact of COVID-19 and strategies for mitigation and suppression." Imperial College London. doi: 10.25561/77735. 
Walters, Glenn D, and P Colin Bolger. 2019. "Procedural justice perceptions, legitimacy beliefs, and compliance with the law: A meta-analysis." Journal of experimental Criminology 15 (3):341372. doi: 10.1007/s11292-018-9338-2.

Weinberger, Daniel A, and Gary E Schwartz. 1990. "Distress and restraint as superordinate dimensions of self-reported adjustment: A typological perspective." Journal of personality 58 (2):381-417. doi: 10.1111/j.1467-6494.1990.tb00235.x.

Wilder-Smith, Annelies, and DO Freedman. 2020. "Isolation, quarantine, social distancing and community containment: pivotal role for old-style public health measures in the novel coronavirus (2019-nCoV) outbreak." Journal of travel medicine 27 (2). doi: $10.1093 / \mathrm{jtm} / \mathrm{taaa} 020$.

Wojcik, Sean P, Arpine Hovasapian, Jesse Graham, Matt Motyl, and Peter H Ditto. 2015. "Conservatives report, but liberals display, greater happiness." Science 347 (6227):1243-1246. doi: 10.1126/science.1260817.

Wolfe, Scott E, Justin Nix, Robert Kaminski, and Jeff Rojek. 2016. "Is the effect of procedural justice on police legitimacy invariant? Testing the generality of procedural justice and competing antecedents of legitimacy." Journal of quantitative criminology 32 (2):253-282. doi: 10.1007/s10940-015-9263-8.

Wright, Austin L, Konstantin Sonin, Jesse Driscoll, and Jarnickae Wilson. 2020. "Poverty and Economic Dislocation Reduce Compliance with COVID-19 Shelter-in-Place Protocols." University of Chicago, Becker Friedman Institute for Economics Working Paper (2020-40).

Zettler, Ingo, Christoph Schild, Lau Lilleholt, and Robert Böhm. 2020. "Individual differences in accepting personal restrictions to fight the COVID-19 pandemic: Results from a Danish adult sample." PsyArXiv Preprint. doi: 10.31234/osf.io/pkm2a.

Zhou, Peng, Xing-Lou Yang, Xian-Guang Wang, Ben Hu, Lei Zhang, Wei Zhang, Hao-Rui Si, Yan Zhu, Bei Li, and Chao-Lin Huang. 2020. "A pneumonia outbreak associated with a new coronavirus of probable bat origin." Nature 579 (7798):270-273. doi: 10.1038/s41586-0202012-7. 
i https://www.rijksoverheid.nl/documenten/mediateksten/2020/03/31/persconferentie-minister-president-rutte-en-minister-de-jonge-over-verlengingcoronamaatregelen

ii https://www.rtlnieuws.nl/nieuws/artikel/5080246/nederland-europa-new-york-lockdown-social-distancing-lombardije-italie

iii https://www.nrc.nl/nieuws/2020/04/01/beroep-op-eigen-verantwoordelijkheid-is-verstandig-a3995622

iv https://www.rijksoverheid.nl/documenten/mediateksten/2020/03/31/persconferentie-minister-president-rutte-en-minister-de-jonge-over-verlengingcoronamaatregelen

v https://www.rijksoverheid.nl/onderwerpen/coronavirus-covid-19/nieuws/2020/02/27/patient-met-nieuw-coronavirus-in-nederland

vi https://www.rijksoverheid.nl/onderwerpen/coronavirus-covid-19/nieuws/2020/03/06/covid-19-nieuwe-aanwijzing-voor-inwoners-noord-brabant

vii https://www.rijksoverheid.nl/actueel/nieuws/2020/03/09/hygienemaatregelen-van-belang-om-verspreiding-coronavirus-tegen-te-gaan

viii https://www.rijksoverheid.nl/actueel/nieuws/2020/03/12/nieuwe-maatregelen-tegen-verspreiding-coronavirus-in-nederland

ix https://www.rijksoverheid.nl/onderwerpen/coronavirus-covid-19/nieuws/2020/03/15/aanvullende-maatregelen-onderwijs-horeca-sport

x https://www.rijksoverheid.nl/onderwerpen/coronavirus-covid-19/nieuws/2020/03/24/aanvullende-maatregelen-23-maart

xihttps:/www.rijksoverheid.nl/onderwerpen/coronavirus-covid-19/nieuws/2020/04/21/maatregelen-corona-verlengd

xii https://www.rijksoverheid.nl/regering/bewindspersonen/mark-rutte/documenten/mediateksten/2020/03/12/persconferentie-minister-president-rutte-en-

minister-bruins-naar-aanleiding-van-de-maatregelen-tegen-verspreiding-coronavirus-in-nederland

xiii https://www.telegraaf.nl/nieuws/420608809/rutte-over-boetes-laat-het-nou-niet-zo-ver-komen

xiv https://www.rijksoverheid.nl/documenten/mediateksten/2020/03/23/persconferentie-minister-president-rutte-ministers-grapperhaus-de-jonge-en-van-rijn-

over-aangescherpte-maatregelen-coronavirus

xv https://www.nrc.nl/nieuws/2020/04/06/coronablog-7-april-a3996067

xvi https://www.parool.nl/nederland/waarom-wil-de-ernst-van-de-coronasituatie-maar-niet-doordringen $\sim$ bba39cd8/

xvii https://www.politie.nl/themas/coronavirus-en-politiewerk.html

xviii https://www.rtlnieuws.nl/nieuws/artikel/5097381/corona-boetes-misdaad-politie-misdrijven-cijfers

xix https://www.rijksoverheid.nl/onderwerpen/coronavirus-covid-19/nieuws/2020/03/24/aanvullende-maatregelen-23-maart

xx https://www.amsterdam.nl/nieuws/nieuwsoverzicht/lenteweekend/

xxi https://www.omroepwest.nl/nieuws/4029924/Gemeente-Lisse-blokkeert-verschillende-wegen-rondom-bollenvelden

xxii https://www.rijksoverheid.nl/onderwerpen/coronavirus-covid-19/nieuws/2020/03/17/coronavirus-kabinet-neemt-pakket-nieuwe-maatregelen-voor-banen-en-

economie

xxiii https://www.rijksoverheid.nl/onderwerpen/coronavirus-covid-19/nieuws/2020/03/26/geen-huisuitzettingen-en-verlenging-tijdelijke-huurcontracten

xxiv In Dutch: “Alleen samen krijgen we corona onder controle: handen wassen, thuisblijven en afstand houden.”

https://www.rijksoverheid.nl/onderwerpen/coronavirus-covid-19/coronavirus-beeld-en-video/communicatiemiddelen-campagne

xxv https://www.rijksoverheid.nl/documenten/mediateksten/2020/03/23/persconferentie-minister-president-rutte-ministers-grapperhaus-de-jonge-en-van-rijn-

over-aangescherpte-maatregelen-coronavirus

xxvi In Dutch: “anderhalvemetersamenleving” https://www.nu.nl/coronavirus/6043769/rutte-nederland-moet-zich-voorbereiden-op-

anderhalvemetersamenleving.html

xxvii https://www.nrc.nl/nieuws/2020/04/16/de-franse-politie-deelde-al-700000-boetes-uit-in-een-maand-tijd-a3996996

xxviii https://www.rtlnieuws.nl/nieuws/artikel/5097381/corona-boetes-misdaad-politie-misdrijven-cijfers

xxix https://www.nhnieuws.nl/nieuws/264236/zandvoort-en-bloemendaal-waarschuwen-na-opnieuw-veel-strandbezoek-blijf-weg

xxx https://www.ad.nl/binnenland/ondanks-lenteweer-trekt-nederland-er-niet-massaal-op-uit-je-kan-op-het-strand-een-kanon-afschieten a3c73762/

xxxi https://nos.nl/artikel/2327903-coronanieuws-21-maart-drukte-op-het-strand-en-bijna-800-italiaanse-doden.html

xxxiihttps://nos.nl/collectie/13824/artikel/2329866-1-5-meter-samenleving-als-nieuwe-normaal-blijf-updaten-en-wees-duidelijk

xxxiii https://depeiling.eenvandaag.nl/?peilingId=115\&tileId=4

xxxiv https://www.volkskrant.nl/columns-opinie/in-het-politieke-coronadebat-zijn-persoon-en-partij-volstrekt-irrelevant b3110358/

xxxv https://www.gstatic.com/covid19/mobility/2020-04-17_NL_Mobility_Report_en.pdf

xxxvi https://www.rijksoverheid.nl/onderwerpen/coronavirus-covid-19/nieuws/2020/04/21/basisscholen-en-kinderopvang-vanaf-11-mei-aangepast-open 